\title{
Introducing PT. Adikarya Multi Teknologi Mandiri Using a Company Profile
}

\author{
Sheryl Keren Muliadie \\ English Department, Faculty of Languages and Literature, Petra Christian University, Siwalankerto 121- \\ 131, Surabaya 60236, INDONESIA \\ Email: Sheryl.muliadie18@gmail.com
}

\begin{abstract}
PT. Adikarya Multi Teknologi Mandiri is a business-to-business company involved in vacuum coating industry. Its folder-shaped company profile specifically targets purchasing personnels and is tailor made to suit procurement process during an open tender; acting as the extension of a name card. Hence, the company profile pays special attention to design that enables easy reading which showcases the company's products and services. Texts are kept short and fully focused on highlighting the company's unique selling preposition to entice offers. The design is based on Gestalt's Principle and Contemporary Color Theory by Steven Bleicher, while the text follows Sally Hogshead's Fascinate: How to Make Your Brand Impossible to Resist and Blythe's Essential of Marketing.
\end{abstract}

Keyword: Business to business, Company Profile, Short Company Profile

\section{INTRODUCTION}

PT. Aditek is B2B (business to business) vacuum coating specialist company. A B2B (business to business) company is a business which "operate in industrial markets acquire goods and services to use in the production of other products or services which are sold, rented, or supplied to other businesses." (Kotler, 2006, p. 20). The company specializes in vacuum coating machine, but also provides other coating machine products and services (spare parts, water treatment, cooling machine, etc.) They first operated as a trading company, but later branched out to provide engineering and consultation services related to vacuum coating. It was built on September 2018 in North Jakarta. Its office is located in Mansion Bougenville BF-31i1, Trembesi Street, Pademangan, North Jakarta. It has only recently obtained its PKP (Pengusaha Kena Pajak-Tax for Businesses) inauguration on June 2019. With a commissary, a director, an engineer, and an accountant; it is a small company that is registered with mid level capital (500 million to 1 billion Rupiah). Due to the lengthy legal process, the company only started its business on paper about a month ago. Its day-to-day operations are funded by engineering services and trading deal, while chasing profits through larger projects such as undertaking machine line creation and machine procurement.

PT. Aditek's competitors were very limited. The company was built due to a market opportunity of localizing vacuum coating services when the industry was exclusively importing (from machineries to engineering). In terms of foreign companies, they are considered more experienced. However, the price that they ask could be 2 to 3 times more than what PT. Aditek requested. Moreover, engineering service would take a while before it can reach the customer (due to the engineer having to fly to Indonesia). Foreign companies who act as competitors are PT. Dah Young Tech Trading, PT. Ulvac, and PT. Pancatama.

The market available for PT. AMTM is promising. In terms of numbers, there are less than 20 companies use vacuum coating machine as of now in Java Island, and the number does not reach 
40 nationally. However, the potential profits for each project is not small. Additionally, the number of customers are expected to rise within the next 5 years.

According to my observation working as an intern in the company, the main problem of the company is the lack of introduction of the company towards its available customers. The company is very recent, so their method of advertisement is through personal visits and word of mouth. They usually give out name cards, but the name cards only contains information about how to contact the staffs, and not what the company is about. It is such a pity that customers do not have a company profile to remind them about the business the company is in, years of experience of the workers, and the products and services available.

To solve the company's problem, I made a company profile. The company profile resembles more of a brochure, with short sentences and numerous pictures. However, it is justified as a B2B style company profile due to the content being wholly representative of the company. It contained USPs and values about the company itself (not just the products and services). A B2B company profile in the painting and coating industry answers to products, company values, and services it provides; which are usually very flexible depending on the market. A company profile that can guide its reader to general and vast information quickly (without fatiguing the reader who has to go through a lot of similar company profiles) about the company can greatly boost the probability of getting called in for a presentation.

\section{Company Profile}

A company profile is a "produk tulisan praktisi PR yang berisi gambaran umum perusahaan. (Company profile is a writing product of PR practices which includes the general overview of a company)" (Kriyantono, 2008, p. 240). Company profile is not merely a description of the company, but also "a quick intro to a company that lets the reader know just who they're reading about." (Company Profile Definition. 2016). Combining the definitions above, a company profile is ultimately a formal introduction that is tailor-made for its target audience. It should be noted, that a company profile is "tidak speneuhnya lengkap, detail, dan mendalam (is not fully thorough, detailed, and exhaustive)" (Kriyantono, 2008, p. 240).

\section{Importance of Company Profile}

There are four functions and importance of a company profile according to Kriyantono (2008, p. 240):

a. Representasi perusahaan (company representation).

b. Melengkapi komunikasi lisan (complementing verbal communication).

c. Menghemat waktu transaksi (lessening transaction time).

d. Membangun identitas dan citra korporat (building company identity and image).

To summarize the given points above, the importance of a company profile is to create a positive concise representation about the company's identity as well as lessening transaction time by providing basic information in meetings with clients.

\section{Company Profile Content}

Writtenhouse (2019) mentioned that a company profile typically includes the following:
a. Business details
b. The Company Basics
c. The Highlights
d. Additional Data 
Notably, there is no exact formula on what to be included in a company profile. Unnecessary texts will distract readers and bore them. According to Steffens (2018), “...hook readers with the facts most relevant to them - so they'll feel more inclined to get all the way to the end." Hence, it is deeply important to be familiar on who the company profile is intended for, along with the target audience's needs and reading habits. As Zambas (2018) said, "To ensure you've got all the right information to entice your reader, you need to turn the traditional business profile on its head and think more about your audience than yourself."

\section{Color Theory}

Based on Bleicher (2012), black is the absence of all color; it represents those who do not give up on anything. In design, black is used as the cover background as it "frames the hue and constrain its visual presence" (p. 79) when outlines other colors. White symbolizes transparency and is often associated with innocence and purity. As a background, white enables color to "visually swell into its space" (p. 79). Any color used on top of black or white will come out strong. Red, on the other hand, is a warm color associated with excitement. When seen, red "increase skin temperature and raise blood pressure and respiration." (p. 48).

\section{Gestalt Principles}

The foundation of Gestalt Principle's Law of Continuation, Law of Proximity, and Law of Unified Connectedness is "The eye tends to build a relationship between elements of the same design," (Soegaard, M. (n.d.)) Thus, by laying out element designs in a certain pattern, the brain will automatically create connections between them. The Law of Continuation uses lines, curves, or shape sequences. Law of Proximity utilizes close distance to group objects. Law of Unified Connectedness uses similarity and differentiation between objects to group each other (Soeegard, M. (n.d.))

\section{METHOD}

The company profile is a $\mathrm{B} 2 \mathrm{~B}$ (business to business) company profile; specifically made to support the company for the start of procurement process during an open tender. It is tailor made for the purchasing department personnel, to make sure they can get the necessary information as effectively as possible (beside machine specification). The job of this company profile is to act as an extension of a name card. Thus, the company profile is concise; containing selected information that is needed to describe the company's business, its experience, and the products and services available.

The first step I took in data gathering was discussions. Armed with questions about the industry, I talked with the director, commissary, and other businessmen related to the field, to get a glimpse about the condition and progress of coating machine in Indonesia. Apparently, 'coating machine' is a board term which includes all sorts of coating method. Depending on the material and necessity, coating methods will differ-from manual hand spray to big chambers. I picked PT. AMTM's product USP from comparing the information in hand.

Next, I decided upon my main reader using the information I acquired by asking around different company directors about open tender process when I was making my company proposal. The target reader is a purchasing staff who works long hours while presumably not getting paid enough to keep up with the arduous tasks assigned to him/her. During the procurement process, the purchasing staff has to read through a lot of machine specifications and company profiles before making the decision which companies are eligible to give a presentation to further present 
their offers. The information that the purchasing staff would want are the machine specification (first and foremost), then a company profile to know the company's credibility and what other products and services are available (for future references) along with the benefits that the company could offer. That being said, I would like to explain that the average human's attention span is 8 seconds and his/her concentration limited to 15 minutes for important tasks (McSpadden, K. (n.d.)). The purchasing staff is presumably fatigued with the amount of offers he/she had to read, so I tailored the company profile to accentuate the important facts that he/she requires to make a (positive) decision. The characteristics of the reader (purchasing) is taken mostly from the commissioners' experience as a purchasing staff as well as through the experience that I have with different purchasing staff during procurement process while helping my father with his company. This is the foundation of the whole company profile.

I dare to be very specific with my target reader because the PT. Aditek's clientele is already particular to big manufacturing companies who coats their products with metal. These companies are set with purchasing departments to sort through offers every time they open tender for projects. The open tender process is also set in stone; the purchasing personnel responsible for the process will sort through offers that fulfills the open tender requested specification and contacts the companies involved for a presentation to the upper management about the detailed plans and price. The job for the purchasing personnel is to sort through offers and see the companies who are offering. Other responsibilities are done by the upper management and it no longer uses company profile because the case would be very specific to the case requested by the client. This is to say that due to the nature of the product and services sold by PT. Aditek, it is impossible to use a company profile for anything other than for a supporting tool to showcase products and services. Everything will need to be dealt by meetings and presentations that are tailored to the customers' requests because it would be too lengthy, arduous, and prone to misunderstandings otherwise. Hence, I will stress that this company profile is solely for open tender process and/or for purchasing department personnel; an extension of a name card. Any other questions and requests are done by e-mail to the company's sales department directly, because PT. Aditek is a trading company that can procure machines without brand limitations. The company also does not have any brands attached to its name that needs to be highlighted.

\section{FINDINGS AND DISCUSSION}

The following paragraph will explain how the theories were applied to the company profile general design, along with the description of the company profile itself.

\section{Shape, Size, and General Design}

Following the Law of Continuity, the company profile is an A4 folder format which pages are connected to one another. The heading and bottom design unified the whole company profile and exert the image of having it as one complete package that roughly translate the company profile as a 'one stop solution' (Soegaard, M. (n.d.)). Each page are then structured using the Rule of Odds with 3 USPs, with the exception of the product page which uses the Law of Proximity.

The unique feature of the company profile is the usage of the Abous Us page as a folder holder which is specifically designed to hold other documents or papers that come with the company profile during a procurement process; such as machine specification, financial statement, quotations, contracts, name cards, etc. The placement of About Us as a folder holder was intentional to give the impression of 'holding the customer's needs as a foundation of the company'. 
Additionally, A4 size is easy to manage, especially when the reader needs to handle numerous documents. A4 is easily carried - too large and it cannot fit in a bag, too small and it will easily be misplaced - and during document sorting, A4 can be quickly seen.

\section{Color}

The color used in the company profile are red, black, and white. These particular colors are picked to represent a strong, dependable company while being pleasantly rapturing visual-wise. The background is predominantly black (especially the cover page). This is to set apart the company profile from others similar to it. I researched that other company profiles from the same industry are either white or multi-colored. Hence, I opted for black. The color black in the background also shapes the white and red font, creating a contrast against the font colors. The matte black background with dual black saturation level, highlights the company's information without hurting the reader's tired eyes. Black is also a sign of stability and dependability. It is a sleek, elegant color, associated with masculinity.

For the content part, I use a predominant white background to create a blank canvas look and draws the reader's attention to the black text. While black is eye-catching and comfortable for the eye, the white is considered an empty color that gauge the reader's concentration to other colors. However, as variation to avoid tiring the eyes, I mixed in black background text boxes for longer texts (such as for engineering page). White speaks of trust and purity (Bleicher, 2012, p. 30); to subtly say that the company is trustworthy.

Red is the breaking attractor. While black and white is attractive on its own, both are monotone colors which need a spark. Red is considered a strong color, the lurer that highlights the reader into the text. Red is associated with anger, but it also meant power (Bleicher, 2012, p. 55). I used red to write the company's USP to create 'powerful words', something that the eye irrevocably drawn into to see.

\section{Description of the Tool}

The shape of the company profile is an A4 folder containing 6 effective pages, 1 cover, and 1 back cover with the inner first page equipped with a half-page folder holder. It uses thick glossy paper with matte finish. The color of the company profile is based on the company's color: red, black, and white. The language used for this company profile is simple, short, and direct; designed to be seen and understood easily in the shortest amount of time. Most of the contents explain using pictures. The reader does not need much concentration in order to understand the content. The content of the company profile will be as such:

\section{Cover page}

Containing the company's logo and company's nickname (PT. Aditek) using font size 144 with red color at the top of the page. Followed by the company's full name in white using font size 48 , and one sentence to explain quickly the company as a vacuum coating specialist. In the middle, in font size 15, is contact details (address, e-mail, and phone number). At the bottom are three strengths, symbolized with icons, that the company could offer to its customers (minimum risk - offering negotiable payment term; personalized service - catering to customers' individual needs; and experienced staff - expert engineers.) The three strength headlines are written in red with font size 18, while the explanations are in white with font size 12. 


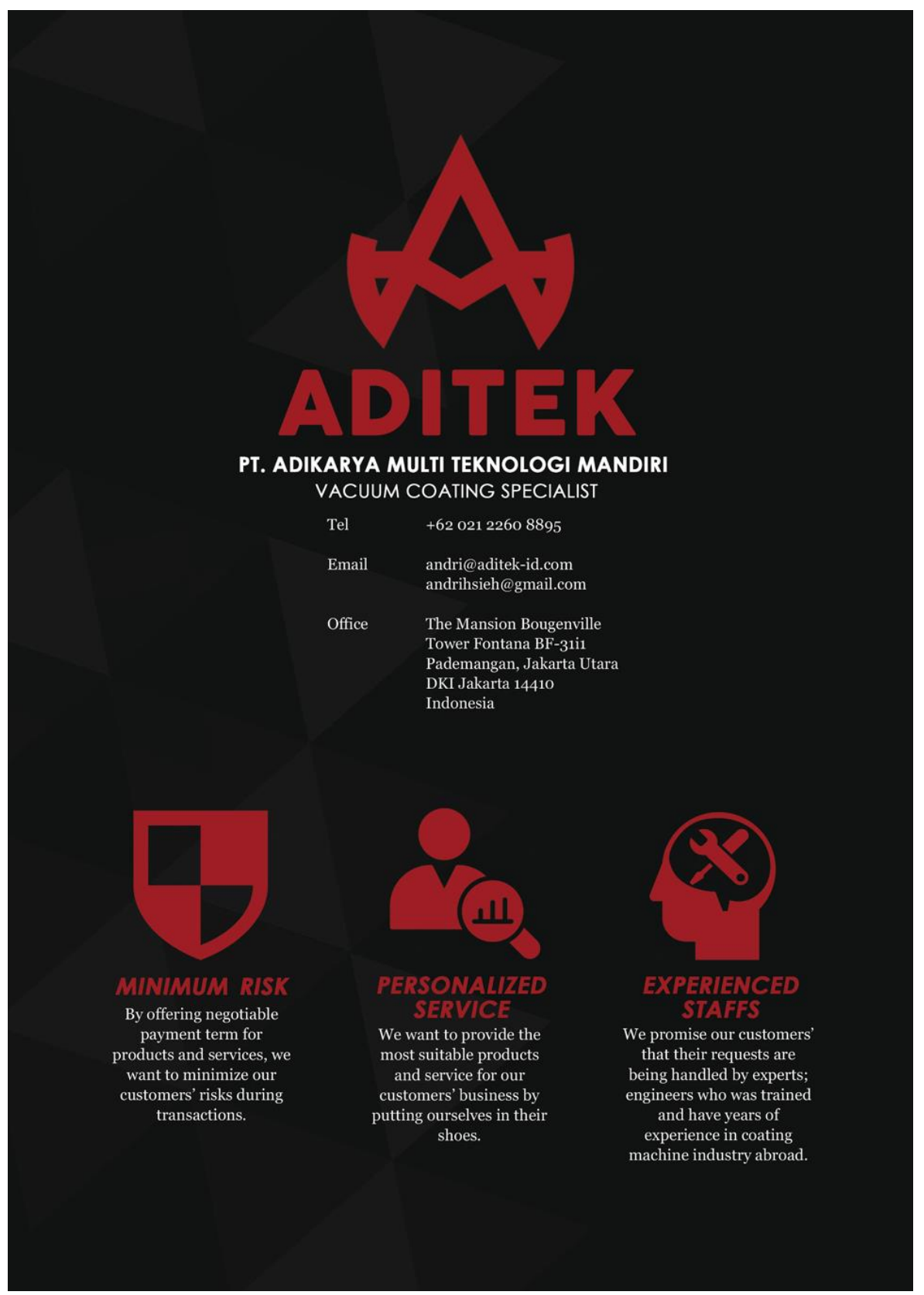

\section{Folder page (inner left)}

Containing the folder holder that is etched with About us, vision, and mission. About Us contains the company's full name below it in grey, font size 14; and two short paragraph in font size 12, white colored. The About Us tells about PT. Aditek's specialty and its personnel's experience in the industry. All the company's USPs are mentioned in the About Us. Below the About Us paragraphs is the vision and mission. Both separated into two red boxes with white fonts, size 12 . 


\section{ABOUT US}

As the first domestic vacuum coating specialist in Indonesia, Aditek aims to provide

customers with the highest quality of products and services with minimum risk. Supported by our staffs' years of training and experience in the coating machine industry in Taiwan, Aditek provides a one-stop solution domestically; from machineries, spare parts, materials,engineering services, to new coating line consultation and vacuum coating line construction.

Through a personalized approach and direct consultation towards our customers' unique needs, Aditek vows to help customers find the most suitable solutions. We offer flexibility through a wide range of coating machine products and services to support our customers throughout their business ventures. We grow alongside our customers as partners, providing our services not only now, but also for years to come.

\section{OUR VISION OUR MISSION}

Being the leading domestic company in providing vacuum coating solution for industries in Indonesia.

$$
\begin{aligned}
& \text { 1. Providing vacuum coating-related } \\
& \text { products and services } \\
& \text { 2. Improving the skills and/or } \\
& \text { knowledge of Indonesian about } \\
& \text { vacuum coating industry } \\
& \text { 3. Lessen the dependency towards } \\
& \text { foreign vacuum coating companies }
\end{aligned}
$$

\section{Product (front right)}

Containing a list of the company's products in the form of pictures with products' name below it. Products are grouped into 5 major categories. One category is reserved for Vacuum Metallizer (VM) as the main highlight - the only category which contain a big picture and a short explanation. Right below it is 'Additional' category, containing Curing Oven and Spray Coating respectively - two non-vacuum coating machine that are commonly used nowadays, caters to middle to low number of coating production which machine cost is cheaper than VM. To the right of VM is the 'Component' category-supporting parts which complements VM in a complete machine line. Below those three categories are "Spare Part" and "Consumables" which are the cheapest among the other three categories but are highly sought after. At the top right of the page is two features that the company offers to make sure that the products are of good quality- to showcase PT. Aditek's USP. 


\section{PRODUCTS \\ " CONTACT US FOR MORE PRODUCTS. WE WILL MAKE IT HAPPEN.}

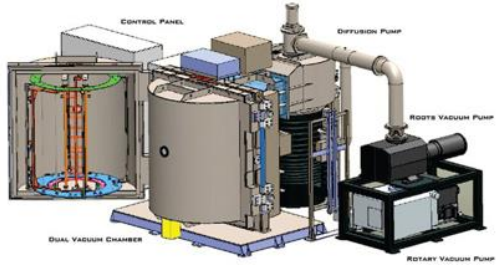

VACUUM METALLIZER

Vacuum Metallizer (VM) is the most cost effective coating machine to date. It is able to coat numerous
products per batch with super thin and even coating layer in a matter of minutes.

\section{ADDITIONAL}

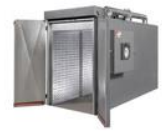

Curing Oven

\section{SPARE PART}

Spray Coating

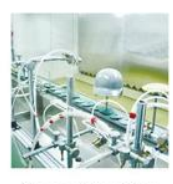

(2) 0

sostiniza
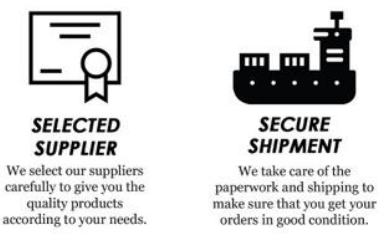

\section{COMPONENT}
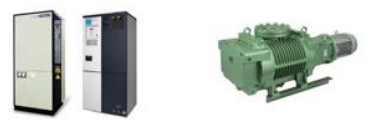

Booster Pump

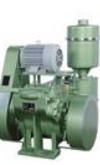

Rotary Pump

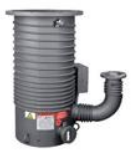

Diffusion Pump

\section{CONSUMABLES}
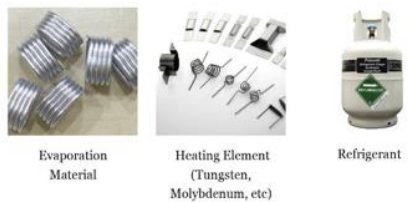

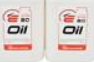
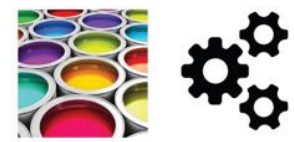

Vacuum Pump Oil

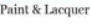

Other consumables
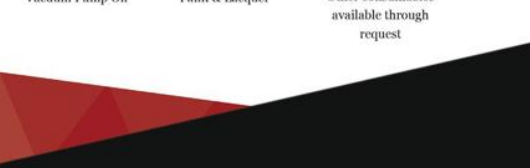

\section{Consultation Service (middle)}

The main service that the company specializes in. Consultation service is about making the whole VM machine line from start to finish. This service generates the most income and is referred as 'project'. A VM image with machine parts name is the highlight of the page. It is followed by three icons with red bold fonts-Thorough after sales, consultant service, and one stop solution - and short explanations below each headline. The three icons also contain PT. Aditek consultation service's strengths. 


\section{CONSULTANT}

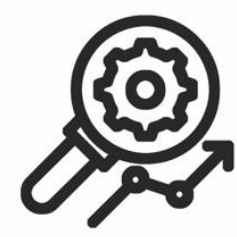

THOROUGH AFTER SALES

After machine installation, we monitor the coating line closely to ensure it is running smoothly. We will check the machine periodically according to previously agreed time frame.

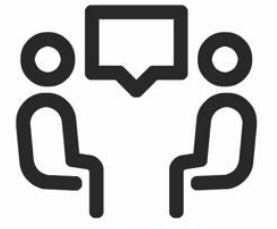

CONSULTANT SERVICE

Our consultation service is the process of hearing our customers' idea then proposing a concrete plan to make it happen. Consultation service will consist of blueprint creation, site visitation, machine procurement, until installation.

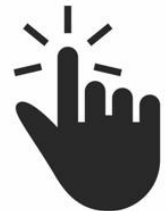

ONE STOP SOLUTION

We offer a one-stop solution for designing tailor-made coating machine line construction. Our services ranges from start to finish; design, machine procurement, installation, and maintenance.

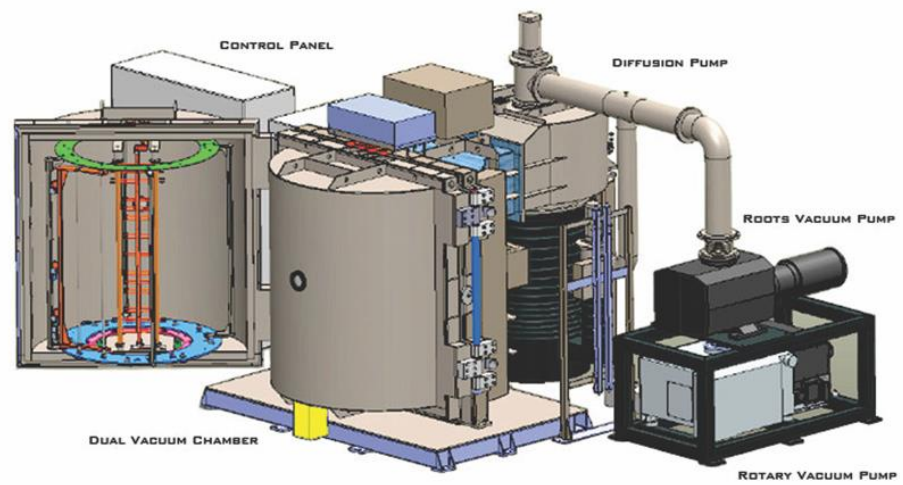

Including: Painting Line, Clean Room, Water Treatment

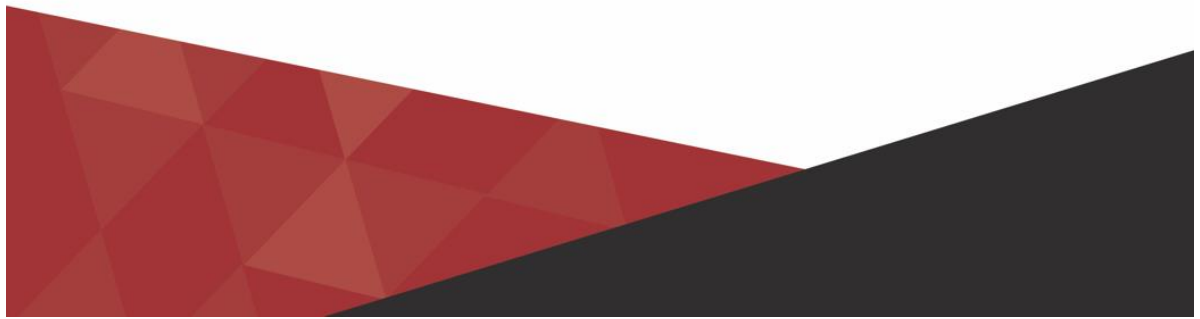

\section{Engineering Service (Inner Right)}

Containing three features about the engineering service quality-responsive engineering service, swift dispatch, and experienced engineers - along with the company's list of engineering services - Installation and MRO-with images 23 representing the headlines. This page is the only page with image and short explanation contained inside a black-colored frame. 

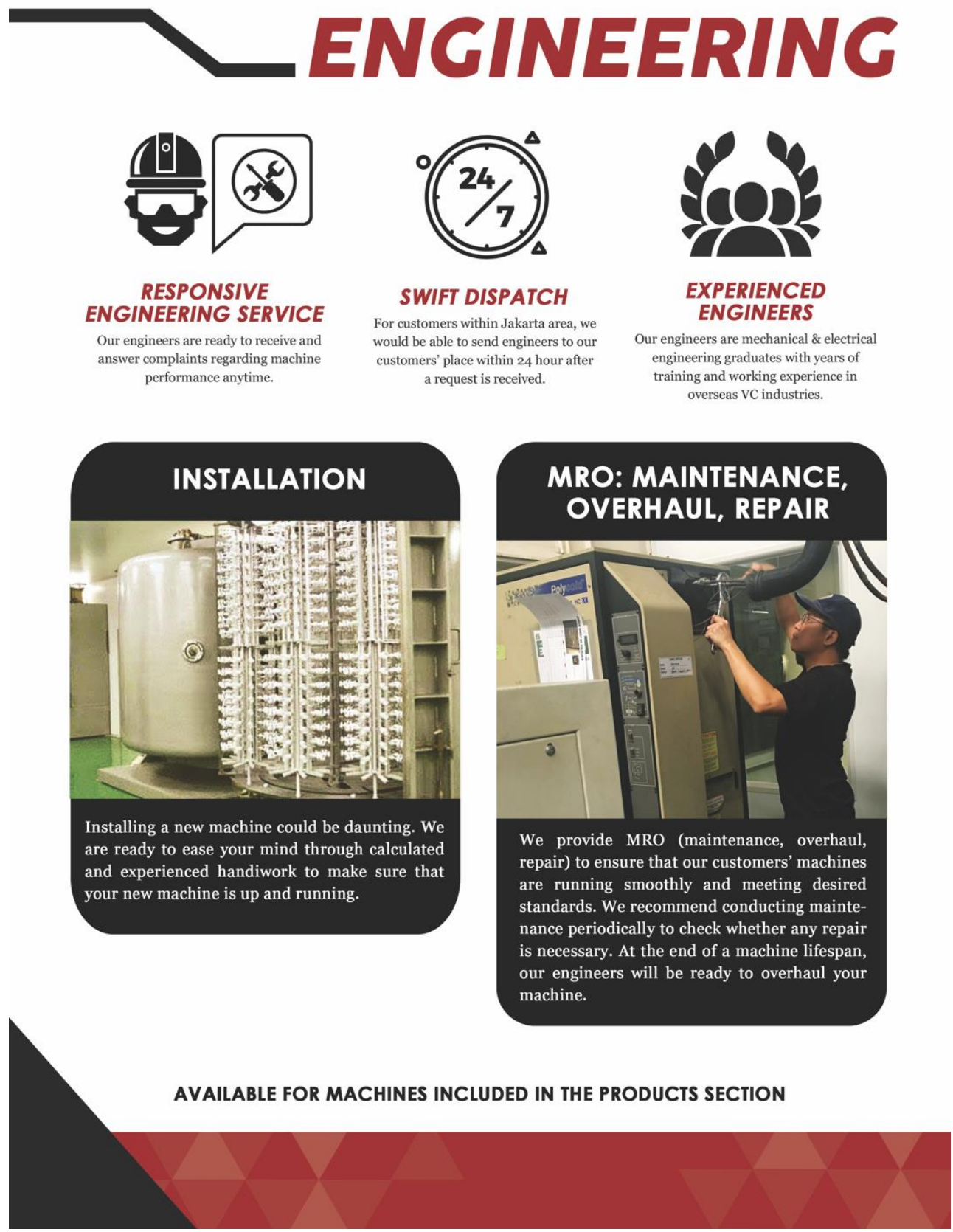

\section{Background Page (Back Cover)}

The background page is based on a simplistic design which contain the company's basic information. The layout and font are perfectly similar with the cover page, without the USPs. 


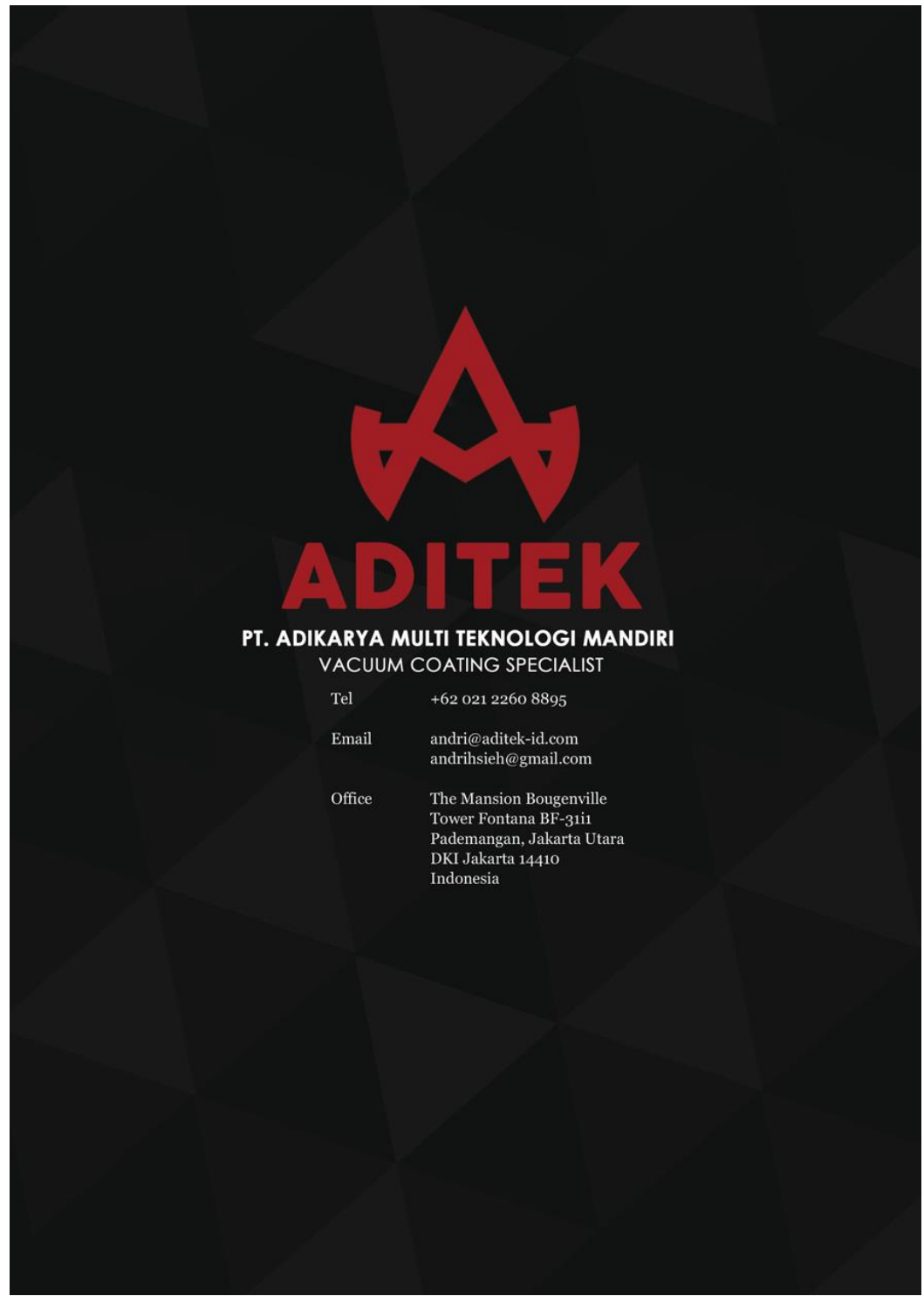

\section{CONCLUSION}

Opting for a project, I was aiming for experience and portfolio that could help me applicate theories I have learned during my university years while contributing towards the company that has mentored me during my internship. PT. Adikarya Multi Teknologi Mandiri (PT. Aditek) is a new B2B company that needs a company profile to help them through open tender process. The company profile will be seen by the clients' purchasing department personnels who want to see the machine specification, plans, quotation, and price list regarding the open tender that the client has published; range of products and services offered by PT. Aditek; and what PT. Aditek specialized in. It should be noted that purchasing personnels have to sort through a lot of company profiles and documents during their working hour; they also already know about the products and services revolved in the industry.

Thus, I made a A4 folder format company profile. It is short, concise, filled with pictures and straightforward text to notify what the readers want to know about PT. Aditek without tiring them. The folder is to contain the machine specification, plans, quotation, price lists, and all information in relation to the open tender (which will differ from company to company). 
The process of making is simple, but long. I started with interviewing the director about the company, deciding the goal of making the company profile, getting to know my target reader's characteristics, reading through a lot of other B2B company profiles for reference, and finally making the general outlook of the company profile. A lot of brainstorming, interviews, and experiments are involved in the making process.

The company will benefit from a straightforward company profile who take into account its target reader first. It is a very specific company profile because its clientele is already specific to big manufacturing companies who have used coating machines and is already roughly informed about the product. Notably, any lengthier explanation is not able to be conveyed through a company profile but can only be discussed directly with the clients, so the company profile is tailored to benefit the company as much as possible through the mechanical way of open tender process which goal is to get called by the purchasing department for a presentation schedule for the upper management. Making a company profile that is easily digestible by the purchasing personnels will increase the chance of getting called while minimizing chances of misunderstandings.

\section{REFERENCES}

Bleicher, S. (2012). Contemporary color: theory \& use. Clifton Park (NY): Delmar cengage learning.

Blythe, J., \& Martin, J. (2019). Essentials of marketing. Harlow, United Kingdom: Pearson Education.

Company Profile Definition: What You Need to Know and More. (2016, November 18). Retrieved from https://www.companyprofilewriter.com/company-profile- definition/.

Kotler, P. (2006). B2B brand management. Heidelberg: Springer.

Kriyantono, R. (2008). Public relations writing: teknik produksi media public relations dan publisitas korporat. Jakarta: Kencana.

Soegaard, M. (n.d.). Laws of proximity, uniform connectedness, and continuation - gestalt principles (2). Retrieved from https://www.interaction-design.org/literature/ article/laws-of-proximity-uniform-connectedness-and-continuation-gestalt- principles-2.

Steffens, R. (n.d.). What to include in your company profile. Retrieved from https:// www.bluleadz.com/blog/what-to-include-in-your-company-profile.

Writtenhouse, S. (2018, November 26). How to write a company profile and the templates you need. Retrieved from https://www.makeuseof.com/tag/company-profile-templates/.

Zambas, J. (2019, October 3). How to write a company profile in 10 simple steps. Retrieved from https://www.careeraddict.com/write-company-profile. 